\title{
Trail Preferences and Visitor Characteristics in Aigüestortes i Estany de Sant Maurici National Park, Spain
}

\author{
Authors: Estela I. Farías Torbidoni, H. Ricardo Grau, and Andreu Camps
}

Source: Mountain Research and Development, 25(1) : 51-59

Published By: International Mountain Society

URL: https://doi.org/10.1659/0276-4741(2005)025[0051:TPAVCI]2.0.CO;2

BioOne Complete (complete.BioOne.org) is a full-text database of 200 subscribed and open-access titles in the biological, ecological, and environmental sciences published by nonprofit societies, associations, museums, institutions, and presses.

Your use of this PDF, the BioOne Complete website, and all posted and associated content indicates your acceptance of BioOne's Terms of Use, available at www.bioone.org/terms-o-use.

Usage of BioOne Complete content is strictly limited to personal, educational, and non - commercial use. Commercial inquiries or rights and permissions requests should be directed to the individual publisher as copyright holder. 


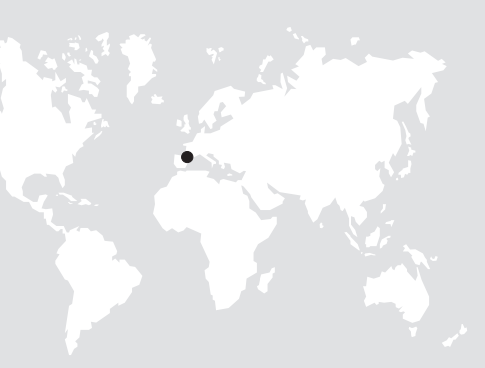

Planning for recreational activities in protected areas involves an understanding of multiple and complex factors. Segmentation of the recreational supply and demand in natural areas, together with identification of

the main conditioning factors of recreational use, are useful for park management. In this study, the recreational supply (trails) and demand (visitor characteristics), as well as some other features of a recreational system, were typologically studied in the Aigüestortes $i$ Estany de Sant Maurici National Park (Lleida, Spain). Through the application of a Multiple Correspondence Analysis (when dealing with demand) and Cluster Analysis (when dealing with both supply and demand), 4 groups of visitors and 3 groups of trails were identified. A positive relationship was observed between the difficulty of the trails and the visitors' educational level, sex, and time spent in the park; and a negative relationship between trail difficulty and the age of the visitors, conservationist perceptions, and demand for accommodation (hotels, mountain lodges, etc). Visitors who were inclined to take either the easiest or the most difficult trails (about 65\% of all visitors) showed group characteristics with the greatest differences. Suggestions for managers of protected areas are discussed, including direct application of information generated by this approach in the recreational management of the Aigüestortes i Estany de Sant Maurici National Park and other natural areas.

Keywords: Demand; supply; recreation; visitor motivation; park management; Pyrenees; Spain.

Peer-reviewed: September 2004 Accepted: November 2004

\section{Introduction}

Recreational activities in protected areas in Spain have significantly increased in recent years. According to government statistics (2002), 10 million people visited some of the 12 Spanish national parks in 2002, in contrast to only 3.9 million visitors in 1990. In accordance with their statutes, the main purposes of Spanish national parks are conservation of the environment and the aesthetics of the landscape, and encouragement of public use and enjoyment of these areas. The increased recreational demand for areas of high ecological value implies potential conflicts between conservation and recreational goals. The number of visitors should be managed either by offering additional facilities or by limiting use, with the aim of maximizing benefits while minimizing conflicts. Three main factors should be considered in recreational planning and management of natural areas: 1) recreational activities, 2) areas visited (in accordance with physical suitability, accessibility, and quality of the scenery), and 3) the expected psychological outcomes or benefits from the experience (Rollins and Rouse 1992).

Several studies of the recreational use of natural areas have focused on the reasons for visitors' choices, including nature, family relationships, risk taking, physical fitness, and general learning. Consequently, classification of demand for recreational use is also a recurrent aim in recreational literature (Knopf 1983). Many studies have classified recreational visitors according to attitude, motivation, resource demand, and infrastructure and landscape preferences (Brown and Haas 1980).

Studies on recreational demand in recent years have focused on the search for interactions between the above-mentioned aspects, such as scenery quality and visitors' satisfaction (Múgica 1993), accessibility and area visited (Rollins and Rouse 1992; Gómez-Limón 1996), physical suitability and recreational activity (Collins and Hodge 1984; Virden and Schreyer 1988; McCool and Reilly 1993), and visitor characteristics and recreational use (Lucas 1980; Harris et al 1984; Hendee and Dawson 2002). These studies emphasize that typological analyses of the recreational supply of, and demand for, natural areas can contribute to the development of management strategies through identification of the main conditioning factors for recreational use. Detailed knowledge of the relationships between the motivation or the socioeconomic characteristics of a particular visitor group and the characteristics of the trails visited may contribute to the design of strategies aimed at increasing visitors' satisfaction without having harmful effects on the protective function of these natural areas. This is particularly important in areas with reduced dimensions and great visitor demand, where the potential for emerging conflicts over use emphasizes the importance of careful planning. In this light, characteristics of visitors and trails were studied in the Aigüestortes i Estany de Sant Maurici National Park, which can be considered a representative example of the general trends in recreational use of protected areas in Spain.

\section{Methodology}

\section{Area studied}

Aigüestortes i Estany de Sant Maurici was established in 1954 with the primary goal of protecting the special 
52

FIGURE 1 Main access to, and principal trails in, Aigüestortes i Estany de Sant Maurici National Park, northern Spain. (Map by Estela I. Farías Torbidoni)

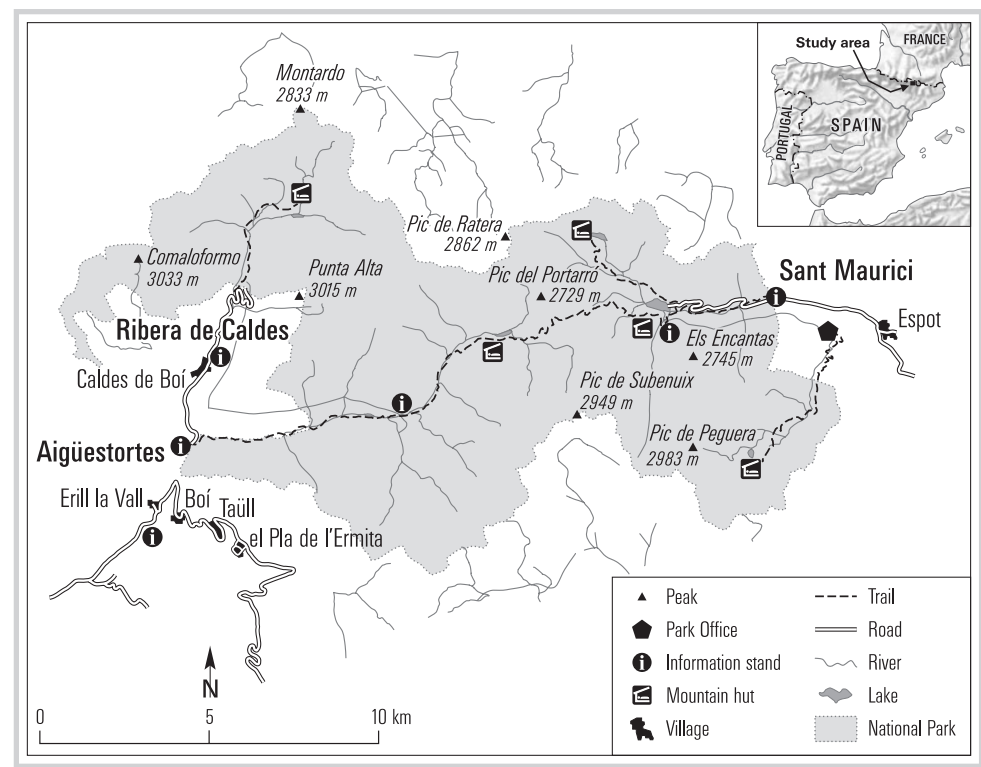

landscape characterized by a large number of lakes and valleys in the Pyrenees. This National Park is the fourth most visited National Park in Spain, with about 500,000 visitors per year, $15 \%$ of whom come from other countries. Figure 1 shows the principal entrances and the most important trails.

The climate of this natural area is characterized by the existence of a variable number of microclimates, conditioned by factors such as elevation, altitude (between 1200 and $3033 \mathrm{~m}$ ), and aspect of valleys and slopes. Annual rainfall (also in the form of snow) in this area is about $1500 \mathrm{~mm}$.

The dominant vegetation includes mixed forests of deciduous trees such as birch (Betula pendula), two types of oak (Quercus humilis and Quercus petraea), the aspen or trembling poplar (Populus tremula) and beech tree (Fagus sylvatica) in the lower areas of the valleys. European silver fir (Abies alba) and dwarf pine (Pinus uncinata) woodlands occur at higher elevations, and alpine meadows dominated by grass of the Festuca genus occur above 2200-2400 m.

\section{Research approach}

The study was conducted during the summer months of 1996. In the summer of 2001, a shorter survey confirmed that the general patterns had not changed (Farías 2001, 2002). The study used the following approaches: 1) the analysis of a visitor typology was based on data obtained from a characteristics and preferences questionnaire; 2) the typology of the trails was based on the results of an analytical method designed for this study, known as the "Recreational Inventory of Natural Resources."

\section{Questionnaire on visitors' characteristics and preferences}

Visitors were classified according to a selection of indices that defined their characteristics, motivations and recreational preferences. The survey included demographic data, visit characteristics, trails visited, facility demand, previous knowledge of the National Park, level of satisfaction, main motivations for the visit, trail choice, and recreational activity. To determine motivation for the visit and recreational activity, respondents were asked to specify the 3 most important reasons out of 9 possible motivations. Reasons for trail choice were defined by asking visitors for the most important choice out of 10 options. They were asked to describe their perception of the environment by choosing from two options: 1) The natural environment is a common asset to take care of and protect, and consequently it is essential to regulate its recreational use; and 2) The natural environment is an additional service for the population in general, and therefore the park administration must improve access and infrastructure at the entrance. Other items included in the questionnaire were obtained from the literature (eg Rollins and Rouse 1992; McCool and Reilly 1993; Wallace and Smith 1997). Twenty-three questions produced a total of 160 derived items, as some were multiple-choice questions.

The survey was conducted with the assistance of voluntary National Park staff trained in field survey techniques. Data were collected every day at the 3 park entrances during the months of July and September 1996, from 12 noon to $8 \mathrm{pm}$, as most of the visitors left the park at this time and the majority of the questions included in this questionnaire referred to activities that had already been carried out (place visited, length of the visit, etc). A total of 796 visitors were interviewed on site. Stratified sampling was based on available data on use patterns in the park, derived from the number of visitors in 1995. Sampling distribution among the points of entry was based on the proportions of visitors registered at the 3 sites during the previous year. Visitors older than 12 years of age were interviewed at any of the 3 entrances when leaving the park. No more than 2 people per group were interviewed, and the average time spent was 8 minutes.

\section{Recreational Inventory of Natural Resources}

The Recreational Inventory of Natural Resources is a system designed to collect information about the main characteristics of different natural recreational resources. Based on United States Department of the Interior, Bureau of Land Management (1972) and Hendee et al (1978), it includes a total of 14 parameters: location, climate, legislation on public use, distance, elevation range, maximum height, slope, trail extent, type of terrain, orientation, trail time (time 
TABLE 1 Multiple Correspondence Analysis: relative contribution of dimensions.

needed to complete the trail), trail difficulty, trail signs, and conservation and landscape aspects.

Milometer wheels were used to measure distances; elevation range, maximum elevation, and slope were derived from topographic maps (scale 1:25,000). Trail times were based on National Park guidebooks and our own measurements of some trails. Conservation and landscape indicators were based on different descriptive tables designed by us. The items included in these tables were obtained from the literature (Gómez-Limón et al 1996; Wright 1974; Robinson 1976; De Lucio and Múgica 1994). The trail inventory was developed in consideration of the principal trail system in the park and the most visited trails, comprising a total of 37 trails, 8 of which lead to a summit.

\section{Data analysis}

Classification of visitors was done using Multiple Correspondence Analysis and Cluster Analysis. Trail classification was done using Cluster Analysis (Ward Method). The chi-square test was used to study the relationship between visitor and trail typologies. Since most of the variables considered in the questionnaires were qualitative, the data analysis questionnaire was analyzed at 2 different stages. First a Multiple Correspondence Analysis was used to reduce the number of group items, from the 160 original items on characteristics and preferences for each visitor to the 5 first dimensions that explained $100 \%$ of the variance (Table 1 ).

In the second stage, a Cluster Analysis was carried out using the Ward Method to classify the Aigüestortes National Park visitors according to the 5 dimensions established with the Multiple Correspondence Analysis (Hair et al 1995). Clusters were based on Euclidean distance measures. Selection of the number of clusters for non-hierarchical clustering procedures is normally a subjective process. In our case, the decision was based on the number of optimal and realistic clusters. For analysis of the recreational natural resource inventory data, Cluster Analysis was performed on indicators relevant to trail difficulty: distance, elevation range, maximum height, steepness, and trail time. In this case, clusters were also based on Euclidean distance measures. The final number of clusters in this analysis was defined by the number of clusters with significant differences in average difficulty indicators for each cluster. The criterion used in this analysis was the Ward Method (Hair et al 1995), which presented the best and most realistic dendrogram.

\section{Results}

\section{Visitor typology}

Four clusters were found to be an optimal solution for the Cluster Analysis of visitors, with one residual group

\begin{tabular}{|c|c|c|c|}
\hline Dimension & Eigenvalue & Contribution & $\begin{array}{c}\text { Cumulative } \\
\text { contribution }\end{array}$ \\
\hline $\mathbf{1}$ & 0.1872 & $(26.1 \%)$ & $26.1 \%$ \\
\hline $\mathbf{2}$ & 0.1479 & $(20.6 \%)$ & $46.7 \%$ \\
\hline $\mathbf{3}$ & 0.1392 & $(19.4 \%)$ & $66.1 \%$ \\
\hline $\mathbf{4}$ & 0.1271 & $(17.7 \%)$ & $83.8 \%$ \\
\hline $\mathbf{5}$ & 0.1142 & $(16.2 \%)$ & $100 \%$ \\
\hline
\end{tabular}

FIGURE 2 Cluster dendrogram obtained through classification of visitors to Aigüestortes National Park, based on their visit characteristics, perceptions and motivations (see Tables 3 and 4). The different names reflect the main characteristics of each group.

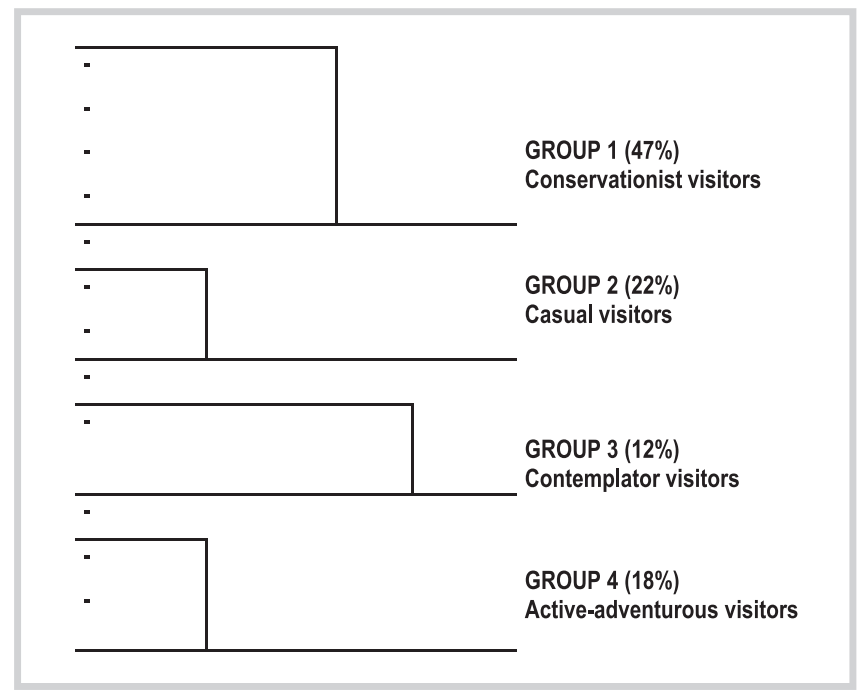

of 9 visitors. The 4 clusters represent the visitor groups or types (Figure 2) and are described below, according to visitors' behavior and recreational motivation.

\section{Group 1: Conservationist Visitors}

This was the largest group, with a total of 374 individuals, $90 \%$ of whom had a conservationist perspective.

They considered the environment as something to care about and to protect, and therefore agreed on the need for control of recreational use. This group included couples and families ( $41 \%$ and $37 \%$, respectively) and many campers $(31 \%)$. Most of them were older visitors, with a nearly equal number of men and women (Table 2). Thirty-eight percent were employees visiting the park for the first time $(77 \%)$. They stayed less than one day, and their trail choice was based on factors such as easy access. The main motivations for this group were to enjoy the landscape and get closer to nature. They accessed the park by taxi, private car, and on foot, in similar proportions (see Table 3). 


\begin{tabular}{|c|c|c|c|c|c|}
\hline \multirow[b]{2}{*}{ Variable } & \multicolumn{5}{|c|}{ Type of visitor } \\
\hline & $\begin{array}{l}\text { Group } 1 \\
(n=374)\end{array}$ & $\begin{array}{c}\text { Group } 2 \\
(n=175)\end{array}$ & $\begin{array}{c}\text { Group } 3 \\
(n=96)\end{array}$ & $\begin{array}{l}\text { Group } 4 \\
(n=142)\end{array}$ & $\begin{array}{c}\text { All cases } \\
(n=796)\end{array}$ \\
\hline \multicolumn{6}{|l|}{ Age group (years) } \\
\hline $17-21$ & 4 & 4 & - & 16 & 6 \\
\hline $22-31$ & 22 & 26 & 28 & 33 & 27 \\
\hline $32-41$ & 32 & 25 & 24 & 18 & 27 \\
\hline$>62$ & 10 & 11 & 13 & 3 & 7 \\
\hline \multicolumn{6}{|l|}{ Sex } \\
\hline Male & 50 & 57 & 71 & 69 & 57 \\
\hline Female & 50 & 43 & 29 & 31 & 42 \\
\hline \multicolumn{6}{|l|}{ Occupation } \\
\hline Student & 12 & 10 & 4 & 43 & 16 \\
\hline Pensioner & 4 & 9 & 14 & 1 & 7 \\
\hline Employee & 38 & 30 & 35 & 22 & 32 \\
\hline \multicolumn{6}{|l|}{ Level of education } \\
\hline Primary or secondary & 17 & 21 & 20 & 10 & 22 \\
\hline Tertiary & 32 & 37 & 40 & 52 & 44 \\
\hline
\end{tabular}

TABLE 2 Variables that best defined the socioeconomic characteristics of the different visitor groups, obtained through classification of visitors to Aigüestortes National Park (see text for details). Values are expressed as the percentage of subjects within each group.
Group 2: Casual Visitors

The 175 individuals in this group can be characterized as casual visitors. They often had little knowledge of the National Park $(70 \%$ did not know the periphery of the park), and it was their first visit (Table 3). Fifty-seven percent were male, $52 \%$ were between 22 and 41 years old, and $39 \%$ were visiting the National Park as part of a couple. Nearly half came by taxi, spent one day (39\%) and either stayed in hotels $(26 \%)$ or had no accommodation $(25 \%)$. Their main motivations were experiencing the National Park area and having a good time. The selection of trails visited was mainly based on recommendations by other people and on the shortness of the trails (Table 4).

\section{Group 3: Contemplator Visitors}

With 96 individuals, this visitor group (71\% male and $14 \%$ pensioner) had the highest percentage of people with previous knowledge of the periphery zone of the park. Fourteen percent visited the park with a family, $67 \%$ came by car, and $26 \%$ stayed in apartments. They typically visited the National Park for half a day (Table 3), and had visited between 2 to 3 times during the previous 2 years $(66 \%)$. The landscape was the principal motivation to visit the park. Most of this group, which can be labeled "contemplator" tourists, entered at Ribera de Caldes (Table 5). Trail choice was often based on a previous visit and activities were aimed at getting closer to nature.
Group 4: Active-adventurous Visitors

This visitor group included 142 individuals (17.8\%), $50 \%$ of whom were between 17 and 31 years old; $69 \%$ were male, $43 \%$ were students, and $52 \%$ had attained the highest educational level. Thirty-seven percent of these visitors came to the park in groups with friends, and $49 \%$ came on foot. Fifty-seven percent were visiting this National Park for the first time. Forty-two percent spent more than two days and $36 \%$ stayed in mountain lodges. Physical activity and new emotions and sensations were the main motivations (Table 4). Trail choice was based on clarity of signs and indications (24\%) and perspective.

\section{Trail typology}

Analysis of a matrix of 37 trails using 5 difficulty parameters resulted in a total of 3 trail groups (Figure 3).

\section{Group 1: Short trails}

This group consisted of 8 trails $(22 \%)$ with a low level of difficulty (Table 6). The average distance was $3.4 \mathrm{~km}$, taking around 68 minutes to complete; the elevation range and the maximum height were $292 \mathrm{~m}$ and $2194 \mathrm{~m}$, respectively.

\section{Group 2: Long trails}

This group included 20 trails characterized by intermediate values between trail groups 1 and 3 (Table 6). Val- 


\begin{tabular}{|c|c|c|c|c|c|c|}
\hline & \multirow[b]{2}{*}{ Variable } & \multicolumn{5}{|c|}{ Type of visitor } \\
\hline & & Group 1 & Group 2 & Group 3 & Group 4 & All cases \\
\hline & \multicolumn{6}{|l|}{ Visiting group } \\
\hline & Couple & 41 & 35 & 37 & 16 & 34 \\
\hline & Family $<2$ people & 37 & 25 & 40 & 9 & 29 \\
\hline & Friends $>6$ people & 11 & 22 & 7 & 37 & 18 \\
\hline & Organized groups & 4 & 10 & 3 & 19 & 9 \\
\hline & \multicolumn{6}{|l|}{ Park access } \\
\hline & Taxi & 31 & 49 & 15 & 18 & 31 \\
\hline & Walking & 33 & 29 & 16 & 49 & 33 \\
\hline & Private car & 33 & 18 & 67 & 25 & 32 \\
\hline & \multicolumn{6}{|l|}{ Accommodation } \\
\hline & No accommodation & 24 & 25 & 18 & 10 & 22 \\
\hline & Hotel & 24 & 26 & 19 & 9 & 21 \\
\hline & Apartment & 8 & 11 & 26 & 3 & 10 \\
\hline & Camping & 31 & 19 & 7 & 12 & 3 \\
\hline & Lodge & 1 & 4 & 4 & 36 & 9 \\
\hline & \multicolumn{6}{|l|}{ Frequency } \\
\hline & First visit & 77 & 82 & 13 & 57 & 67 \\
\hline & $2-3$ visits & 18 & 15 & 66 & 28 & 25 \\
\hline & \multicolumn{6}{|l|}{ Time spent in the park } \\
\hline & 1/2 day & 37 & 38 & 48 & 13 & 35 \\
\hline & 1 day & 41 & 39 & 44 & 15 & 36 \\
\hline & $2-3$ days & 10 & 17 & 6 & 42 & 17 \\
\hline & \multicolumn{6}{|l|}{ Knowledge of park } \\
\hline defined the characteristics of & Yes & 41 & 30 & 76 & 65 & 47 \\
\hline $\begin{array}{l}\text { through classification of visitors to } \\
\text { Aigüestortes National Park. }\end{array}$ & No & 59 & 70 & 24 & 35 & 53 \\
\hline
\end{tabular}

ues for time, distance and elevation range in this group are between 2 and 3 times those of group 1. The maximum time for these trails was 195 minutes for a $9-\mathrm{km}$ trail.

\section{Group 3: Trails ending on a mountaintop}

This group included 9 trails, all of which end on a mountain summit. In general, these trails were longer, went higher, were steeper, had a larger elevation range, and took longer to walk than any of the trails in the other 2 groups (Table 6).

\section{Visitor types versus trail typology}

Using the different groups obtained in the typology of visitors and trails, the existence of significant associations between trail groups and visitor groups can be observed (Table 7). The survey shows that most visitors to Aigüestortes National Park chose short trails (32\%) or stayed at their place of arrival $(28 \%)$. This was the pattern for the Conservationist Visitors and Casual Visitors (groups 1 and 2, respectively), who had similar trail choices (Table 7) and shared some characteristics such as occupation, visiting group, time spent in the park, 


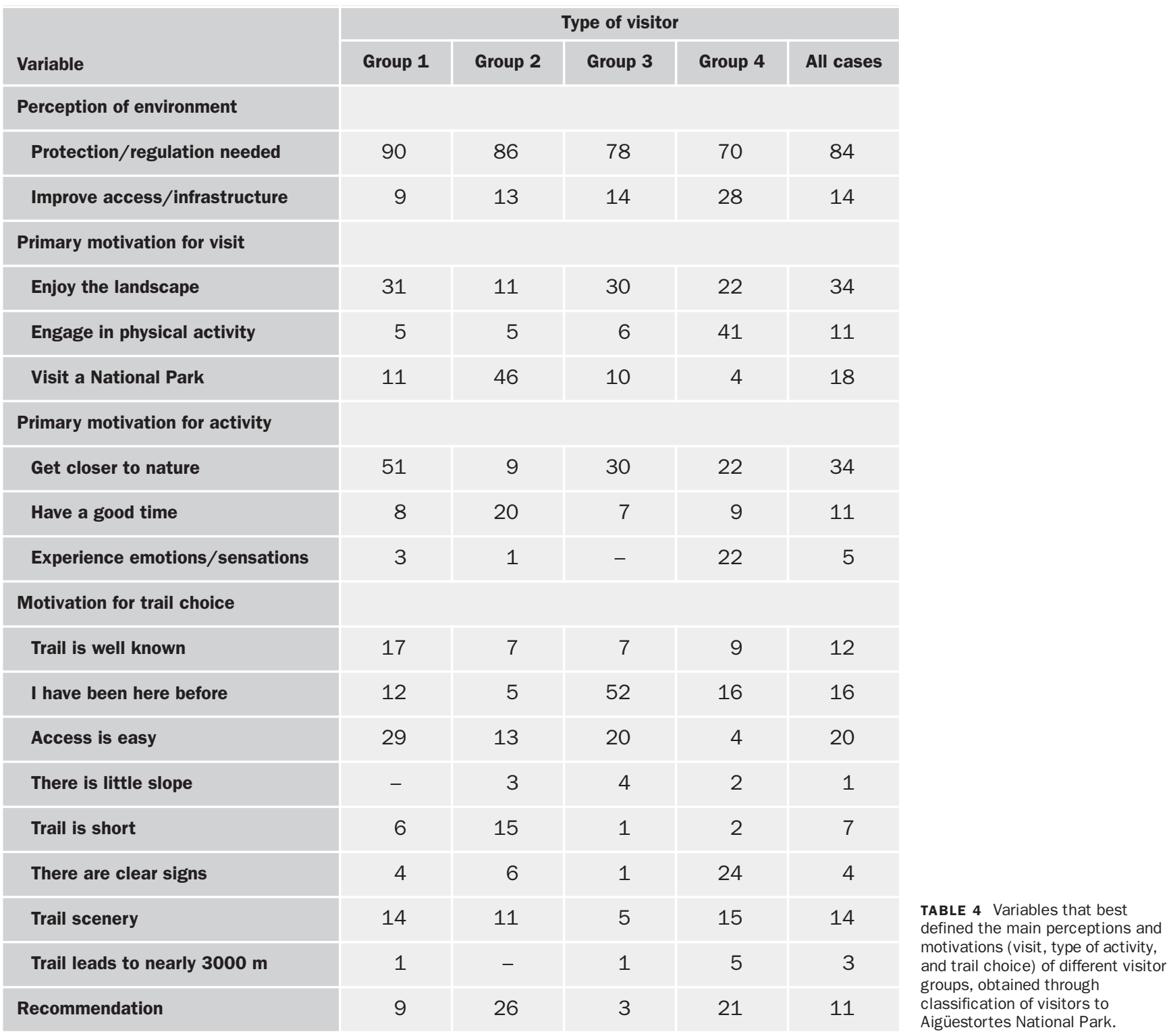

TABLE 5 Distribution based on access for the different visitor groups. Values are expressed as percentages of subjects within each group.

\begin{tabular}{|c|c|c|c|c|c|}
\hline Access & $\begin{array}{l}\text { Group } 1 \\
(n=374)\end{array}$ & $\begin{array}{l}\text { Group } 2 \\
(n=175)\end{array}$ & $\begin{array}{c}\text { Group } 3 \\
(n=96)\end{array}$ & $\begin{array}{l}\text { Group } 4 \\
(n=142)\end{array}$ & $\begin{array}{l}\text { All cases } \\
(n=796)\end{array}$ \\
\hline Sant Maurici & 44 & 42 & 10 & 42 & 39 \\
\hline Aigüestortes & 19 & 34 & 16 & 15 & 22 \\
\hline Ribera de Caldes & 37 & 24 & 74 & 42 & 39 \\
\hline
\end{tabular}

and motivation for trail choice (Tables 3 and 4). Contemplator Visitors and Adventurous Visitors (visitor groups 3 and 4, respectively) had different preferences and characteristics. Adventurous Visitors walked through the park $(33 \%)$, and chose either trails that ended on a peak $(20.4 \%)$ or long trails $(26 \%)$, options that were not popular among groups 1 and 2 (Table 7).
Moreover, they were mainly students, visited the park with friends, came for 2 or 3 days, and their trail choice depended on proper trail signs, in contrast with groups 1 and 2. Contemplator Visitors preferred to stay at their place of arrival or chose longer trails, in contrast to Conservationist Visitors and Casual Visitors, with few people taking trails that ended on a peak (Table 7). 
FIGURE 3 Cluster dendrogram obtained through the classification (Ward Method) of Aigüestortes National Park trails, based on characteristics listed in Table 6. The numbers $(1,2$, and 3$)$ correspond to increased difficulty.

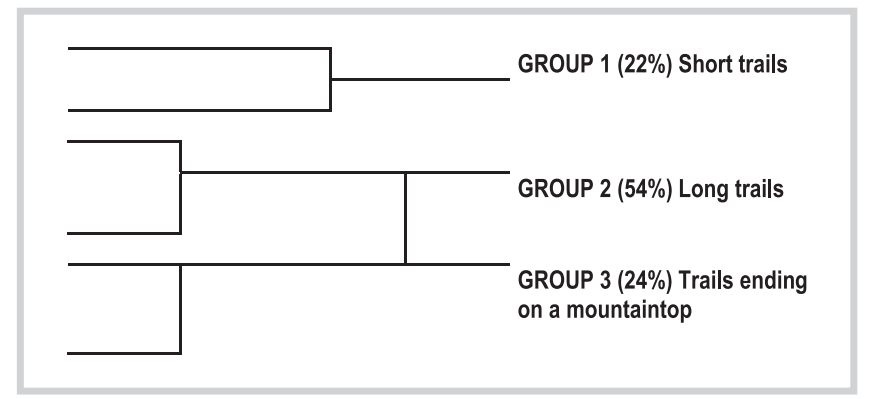

TABLE 6 Mean, minimum, and maximum values for difficulty indicators obtained for the 3 different trail groups. Group 1: short trails, Group 2: long trails, Group 3: trails ending on a mountain peak.

\begin{tabular}{|c|c|c|c|c|c|c|c|c|c|}
\hline \multirow[b]{2}{*}{ Indicators } & \multicolumn{3}{|c|}{ Group 1 (22\%) } & \multicolumn{3}{|c|}{ Group 2 (54\%) } & \multicolumn{3}{|c|}{ Group 3 (24\%) } \\
\hline & Mean & Min & Max & Mean & Min & Max & Mean & Min & Max \\
\hline Time (min) & 68 & 45 & 90 & 150 & 105 & 195 & 248 & 225 & 330 \\
\hline Altitudinal range $(\mathrm{m})$ & 244 & 130 & 292 & 608 & 394 & 851 & 1133 & 950 & 1361 \\
\hline Distance (m) & 3426 & 2037 & 4807 & 6404 & 4027 & 9022 & 7247 & 4361 & 12,225 \\
\hline Maximum height (m) & 2010 & 1617 & 2194 & 2334 & 1820 & 2733 & 2920 & 2733 & 3017 \\
\hline Slope (\%) & 7 & 5 & 11 & 9 & 6 & 14 & 17 & 11 & 29 \\
\hline
\end{tabular}

TABLE 7 Results of the relation between visitor and trail typologies obtained through a chi-square test. Percentages correspond to the trail preferences of the 4 visitor groups analyzed.

\begin{tabular}{|c|c|c|c|c|c|c|}
\hline \multirow[b]{2}{*}{ Trail typology } & \multicolumn{6}{|c|}{ Type of visitor } \\
\hline & $\begin{array}{c}\text { Chi- } \\
\text { squared }\end{array}$ & Sig. & $\begin{array}{c}\text { Group } 1 \\
(47 \%)\end{array}$ & $\begin{array}{c}\text { Group } 2 \\
(22 \%)\end{array}$ & $\begin{array}{c}\text { Group } 3 \\
(12 \%)\end{array}$ & $\begin{array}{c}\text { Group } 4 \\
(18 \%)\end{array}$ \\
\hline Stayed at place of arrival & 76.6 & .000 & $31.9 \%$ & $26.3 \%$ & $40.7 \%$ & $6.3 \%$ \\
\hline Short trails & 44.4 & .000 & $40.4 \%$ & $40.7 \%$ & $13.5 \%$ & $14.0 \%$ \\
\hline Long trails & 209 & .000 & $21.4 \%$ & $21.1 \%$ & $31.2 \%$ & $26.0 \%$ \\
\hline Trails ending on a peak & 5.4 & .000 & $2.1 \%$ & $2.8 \%$ & $9.4 \%$ & $20.4 \%$ \\
\hline Trail crossing National Park & 30.5 & .000 & $4.2 \%$ & $9.1 \%$ & $5.1 \%$ & $33.3 \%$ \\
\hline
\end{tabular}

Considering the Conservationist Visitors and the Casual Visitors as the groups that chose the easier trails, and the Contemplator and Adventurous groups as those that chose the more difficult trails, an indirect relationship can be observed between the level of trail difficulty and the demand on resources that gave the visit a great deal of satisfaction (accessibility, lodging and motivation for trail choice). For example, while the Conservationist and Casual Visitor groups tended to come to the National Park by car, lodged in hotels, and mainly chose trails with easy access, the Adventurous Visitors group tended to come on foot, stayed principally in mountain lodges, and chose trails mainly based on the clarity of the signs.

\section{Discussion}

The present study revealed that: a) trail choice is basically conditioned by the degree of accessibility and difficulty, with the most accessible and less difficult trails being the 
most visited; b) other factors contribute to trail choice, such as the popularity of the place, the beauty of the scenery, and recommendation by park staff. As in other studies (McCool and Reilly 1993; Gómez-Limón et al 1994; Watson et al 1996), accessibility and satisfaction were found to be critical factors in visitors' trail choices.

The results obtained for trail preference patterns supplement existing information and emphasize the importance of visitor characteristics (age, sex, professional status, and level of education), characteristics of the area (accessibility, lodging facilities), time spent in the park, visit frequency, type of visitor group (couple, family, or friends), and the main motivation for visiting the area. Conservationist and Casual Visitors, for example, mostly chose short trails, and Adventurous Visitors mostly long trails or trails ending on a peak.

For management purposes, it is important to know that the generic profiles of visitors and their trail preferences were not homogeneous, but could be grouped using relatively simple statistical methods. Although not all visitors' expectations or needs can be satisfied, consistent classification of individuals into groups with shared preferences provides a baseline classification for identifying the characteristics of recreational demand and its associations with park resources.

In order to plan recreational use compatible with the protection of a natural area, the following guidelines should be taken into consideration:

1) Correct trail choice contributes to visitor satisfaction (as a function of performance, expectation and motivation), and

2) The degree of conservation in a certain area can be conditioned by the level of recreational use, which in turn can be modified in accordance with the main characteristics of demand in that area.

The key factors in trail choice identified here (eg accessibility, lodging, and motivation for trail choice) should be clearly described in brochures or maps with a decision-tree format (Krumpe and Brown 1982) that can be tailored to specific visitor groups (eg Adventurous Visitors). The individual visitor categories may be used as a basis for assessment of recreational benefits and examining different attitudes. Consequently, models of park use for different visitor types can be developed.

\section{AUTHORS}

Estela I. Farías Torbidoni

Passeig Moragues $172^{\circ} 2^{\circ}$, Castelldans, 25154 Lleida, Spain.

estela.farias@cag.es

\section{H. Ricardo Grau}

LIEY, cc 34, 4107 Yerba Buena, San Miguel de Tucuman, Argentina.

chilograu@yahoo.com.ar

Andreu Camps

INEFC, Partida la Caparella, s/n, 25000 Lleida, Spain.

acamps@inefc.es

\section{REFERENCES}

Brown PJ, Haas GE. 1980. Wilderness recreation experiences: The Rawah case. Journal of Leisure Research 2:229-241.

Collins R, Hodge I. 1984. Clustering visitors for recreation management. Journal of Environmental Management 19(2):147-158.

De Lucio JV, Múgica M. 1994. Landscape preferences and behaviour of visitors to Spanish national parks. Landscape and Urban Planning 29:145-160.

Farías EI. 2001. El aprovechamiento recreativo del Parc Nacional d'Aigüestortes i Estany de Sant Maurici. Frecuentación, caracterización de visitantes e impactos ambientales [Memorandum presented at the Generalitat de Catalunya]. Lleida, Spain: Patronato Parc Nacional de Aigüestortes i Estany de Sant Maurici.

Farías EI. 2002. L'enquesta com a eina d'estudi per a la gestió recreativa del medi natural. Revista del Centre de Biodiversitat de Andorra. Hábitats 5:16-27.

Farias EI, Camps A. 2000. El aprovechamiento recreativo, deportivo y turístico de los espacios naturales protegidos. Modelos de frecuentación. El caso del Parc Nacional d'Aigüestortes i Estany de Sant Maurici [PhD dissertation]. Lleida, Spain: Universidad de Lleida.

Gómez-Limón FJ. 1996. Uso Recreativo de los Espacios Naturales. Frecuentación, factores explicativos e impactos asociados. El caso de la comunidad de Madrid [PhD dissertation]. Madrid, Spain: Facultad de Ciencias, Departamento Interuniversitario de Ecología, Universidad Autónoma de Madrid.

Gómez-Limón FJ, Múgica M, Medina L, De Lucio JV. 1994. Áreas recreativas en la Comunidad de Madrid. Afluencia de visitantes y actividades desarrolladas. Madrid, Spain: Centro de Investigación "Fernando González Bernáldez." Gómez-Limón FJ, Múgica M, Muñoz C, De Lucio JV. 1996. Uso recreativo de los espacios naturales en Madrid. Frecuentación, caracterización de visitantes e impactos ambientales. Madrid, Spain: Centro de Investigación "Fernando González Bernáldez" and Consejería de Medio Ambiente y Desarrollo Regional.

Hair JF, Anderson RE, Tathan RL, Black WC. 1995. Multivariate Data Analysis with Readings. Englewood Cliffs, NJ: Prentice Hall. 
Harris CC, Driver BL, Bergensen EP. 1984. Do choices of sport fisheries reflect angler preferences for site attributes? In: Proceedings of the Symposium on Recreation Choice Behavior. General Technical Report INT-184. Ogden, UT: USDA [United States Department of Agriculture] Forest Service and Intermountain Research Station, pp 15-25.

Hendee JC, Clark RN, Hogans ML, Wood D, Koch RW. 1978. Code-a-site: A System for Inventory of Dispersed Recreation Sites in Roaded Areas, Back Country and Wilderness. Research Paper PNW-209. Portland, OR: USDA [United States Department Agriculture] Forest Service.

Hendee JC, Dawson CP. 2002. Wilderness Management: Stewardship and Protection of Resources and Values. Third Edition. Golden, CO: Fulcrum Publishing.

Knopf RC. 1983. Recreational needs and behaviour in natural settings. In: Altman I, Wohlwill J, editors. Behaviour and the Natural Environment. New York: Plenum Press, pp 1-83.

Krumpe EE, Brown PJ. 1982. Redistributing backcountry use through information related to recreation experiences. Journal of Forestry 80:360-364. Lucas RC. 1980. Use Patterns and Visitor Characteristic Attitudes and Preferences in Nine Wilderness and Other Roadless Areas. Research Paper INT253. Ogden, UT: USDA [United States Department of Agriculture] Forest Service and Intermountain Research Station.

McCool SF, Reilly M. 1993. Benefit segmentation analysis of state park visitor preferences and behavior. Journal of Park and Recreation Administration 11(4):1-14.

Múgica M. 1993. Modelos de demanda paisajística y uso recreativo de los espacios naturales [PhD dissertation]. Madrid, Spain: Facultad de Ciencias, Departamento Interuniversitario de Ecología, Universidad Autónoma de Madrid.

Robinson RD. 1976. Landscape Evaluation. Manchester, UK: University of Manchester.

Rollins RB, Rouse J. 1992. Segmenting backcountry visitors by setting preferences. In: Willison JHM, editor. Science and the Management of Protected Areas. Proceedings of an international conference held at Acadia University, Nova Scotia, Canada, 14-19 May 1991. New York: Elsevier, pp 485-497.

United States Department of the Interior, Bureau of Land Management. 1972. Recreational Inventory System. BLM Man. Sect. 6110. Washington, DC: United States Department of the Interior, Bureau of Land Management, pp 1-35.

Virden RJ, Schreyer R. 1988. Recreation specialization as an indicator of environmental preference. Environment and Behavior 20(6):721-739.

Wallace GN, Smith MD. 1997. A comparison of motivations, preferred man agement actions, and setting preferences among Costa Rica, North American and European visitors to five protected areas in Costa Rica. Journal of Park and Recreation Administration 15(1):59-82.

Watson A, Hendee J, Zaglauer H. 1996. Human values and codes of behavior: Changes in Oregon's eagle cap wilderness visitors and their attitudes. Natural Areas Journal 16(2):89-93.

Wright G. 1974. Appraisal of visual landscape qualities in a region selected for accelerated growth. Landscape Planning 1:307-327. 